\title{
Effect of nest age and habitat variables on nest survival in Marsh Harrier (Circus aeruginosus) in a fishpond habitat
}

\author{
Urszula Zaremba $^{\text {Corresp., } 1}$, Zbigniew Kasprzykowski ${ }^{1}$, Artur Goławski ${ }^{1}$ \\ ${ }^{1}$ Faculty of Exact and Natural Sciences, Siedlce University of Natural Sciences and Humanities, Siedlce, Poland \\ Corresponding Author: Urszula Zaremba \\ Email address: uz525@stud.uph.edu.pl
}

Background

One important anti-predator strategy adopted by birds involves nest site selection and timing of breeding. Nest-site selection by marsh-nesting birds often involves nest concealment and water depth as key features influencing nest survival. Marsh Harrier (Circus aeruginosus) is an obligate ground nester, which sets it apart from other raptors. The aim of the present study was to identify for the first time possible temporal and habitat factors affecting nest survival in Marsh Harrier. Understanding features which affect nest survival are essential for assessing relevant conservation strategies.

Methods

To understand the relative contributions of different temporal and habitat variables to brood losses, it is useful to determine the daily survival rate (DSR). We examined 82 Marsh Harrier nests located on fishponds in eastern Poland, where predation is the main cause of nest loss. Six habitat variables were measured for each active nest. DSR was calculated using known-fate models with the RMark package.

Results

The best-supported model predicted that DSR decreased with nest age and was positively affected by the water depth and the diameter of reed stems, but not by the height or density of vegetation at the nest site. The distances of nests to the fishpond dyke and to open water received no support in the models. The chances of nest survival were lower if a neighbouring nest had been depredated. This result suggests that Marsh Harrier is more susceptible to mammalian than avian predation and confirm the high level of predator pressure in fishpond habitats. 
1 Effect of nest age and habitat variables on nest survival in Marsh Harrier (Circus aeruginosus) in

2 a fishpond habitat

4 Urszula Zaremba, Zbigniew Kasprzykowski, Artur Goławski

5

6 Faculty of Exact and Natural Sciences, Siedlce University of Natural Sciences and Humanities,

7 Prusa 14, 08-110 Siedlce, Poland

8

9 Corresponding Author:

10

Urszula Zaremba

Email address: ula.zaremba@gmail.com

\section{ABSTRACT}

Background

One important anti-predator strategy adopted by birds involves nest site selection and timing of breeding. Nest-site selection by marsh-nesting birds often involves nest concealment and water depth as key features influencing nest survival. Marsh Harrier (Circus aeruginosus) is an obligate ground nester, which sets it apart from other raptors. The aim of the present study was to identify for the first time possible temporal and habitat factors affecting nest survival in Marsh Harrier. Understanding features which affect nest survival are essential for assessing relevant conservation strategies.

\section{Methods}

To understand the relative contributions of different temporal and habitat variables to brood losses, it is useful to determine the daily survival rate (DSR). We examined 82 Marsh Harrier nests located on fishponds in eastern Poland, where predation is the main cause of nest loss. Six habitat variables were measured for each active nest. DSR was calculated using known-fate models with the RMark package.

Results

The best-supported model predicted that DSR decreased with nest age and was positively affected by the water depth and the diameter of reed stems, but not by the height or density of vegetation at the nest site. The distances of nests to the fishpond dyke and to open water received 
no support in the models. The chances of nest survival were lower if a neighbouring nest had been depredated. This result suggests that Marsh Harrier is more susceptible to mammalian than avian predation and confirm the high level of predator pressure in fishpond habitats.

Keywords: Breeding time, Fishpond, Nest site selection, Predation risk, Daily survival rate

\section{INTRODUCTION}

Nesting habits of Harriers (Circus spp) sets them apart behaviorally from other raptors - they are the only diurnal birds of prey which nest on the ground. Species across this genus share more unique characteristics which makes them highly adapted to life style in open grasslands and wetlands such as ability to transfer prey in aerial food-pass or foraging at high resolution acoustical abilities (Simmons, 2000). Generally, ground nesting among diurnal birds of prey is sometimes observed in areas where predation pressure is relaxed for instance in isolated areas or areas without human disturbance (Ellis et al., 2009). The Marsh Harrier (Circus aeruginosus) is a migrant species, which prefers semi-open habitats with extensive reedbeds (Alves et al., 2014). The typical biotopes of Marsh Harriers are the shores of lakes and fishponds covered with reed, peat bog areas covered with reed and willow as well as small midfield ponds in agriculturalwetland complex mosaic (Witkowski, 1989). Marsh Harrier build nest in aquatic vegetation above the water surface and exceptionally also in cereal fields or meadows. This unique nesting behaviour makes this species a particularly interesting object of study in the context of factors affecting the risk of nest loss, especially those resulting from predation. The influence of habitat features on predation risk is an aspect still largely unexplored in this species.

Predation is one of the most important selective pressures in nature, and birds display a variety of behavioural traits that appear to be adaptations to prevent predators from detecting their nests (Caro, 2005; Ibáñez-Álamo et al., 2015; Pestana, Mateus-Barros \& GuillermoFerreira, 2020). Anti-predator strategies adopted by birds involve direct effects of parental behaviour (nest defence) as well as indirect ones, such as the decision where (nest site selection) and when (timing) to breed (Lima, 2009). Numerous studies have shown that, for many typical marsh-nesting birds, water depth and emergent vegetation are key features influencing nest site selection and nest survival (Sutherland \& Maher, 1987; Polak, 2007; Austin \& Buhl, 2011).

Nesting success tends to increase with increasing depth of water under the nest (Albrecht et al., 
2006; Polak, 2016). It has been demonstrated that water acts as a barrier and limits access to a nest for many terrestrial predators (Jobin \& Picman, 1997; Hoover, 2006). Vegetation cover is expected to reduce transmission of auditory and visual cues from a nest to potential avian and mammalian predators, so the better a nest is concealed among reedbed vegetation, the lower the risk of its being detected. Vegetation features such as height (Jedlikowski, Brzeziński \& Chibowski, 2015; Batáry \& Báldi, 2005) and density (Kristiansen, 1998; Polak, 2016) contribute to nest concealment and positively influence nest survival in marsh nesting birds. Moreover, some studies have shown that factors associated with macro-scale nest placement, such as the distances from the nest to open water and the land-water margin, also affect the risk of nest loss (Brzeziński, Jedlikowski \& Żmihorski, 2013; Jedlikowski, Brzeziński \& Chibowski, 2015). Besides nest concealment, another factor affecting nest survival could be the fate of the nearest neighbouring nest. If a predator has found one nest in an area, there is a greater chance that it will locate similar nests close to one another (Kristiansen, 1998; Kasprzykowski \& Polak, 2014). In order to better understand the relative contributions of different temporal and nest site characteristics to nest survival, it is useful to determine the daily survival rate (DSR), i.e. the probability that a nest survives a single day (Dinsmore, White \& Knopf, 2002). To date, daily nest survival models have been used mainly for waterfowl, shorebirds, and passerines that nest on or near the ground (Davison \& Bollinger, 2000; Grant et al., 2005; Smith \& Wilson, 2010); only a few studies of raptors have analysed this pattern (Brown \& Collopy, 2008; Brown et al., 2013; Crandall, Bedrosian \& Craighead, 2015, Segura \& Bó, 2018). The aim of the present study was to investigate for the first-time key factors affecting the nest survival rate in Marsh Harrier in wetland habitats with varied vegetation structures and hydrological regimes. Vegetation and wetland characteristics are important factors affecting nest site selection in this species (Stanevičius, 2004; Němečková, Mrlík \& Drozd, 2008). In addition, nest site selection appears to be affected not only by nesting habitat quality but also by the presence of conspecifics using the nearby wetland as a foraging area (Cardador, Carrete \& Manosa, 2011).

In the present research, answers were sought to the following questions: (1) Does nest age influence Marsh Harrier DSR in a wetland habitat? (2) Does the Marsh Harrier nest DSR pattern differ from that of birds well adapted to nesting in aquatic environments? (3) What is the effect of different habitat characteristics on Marsh Harrier nest DSR? (4) Is the fate of the nearest neighbouring Marsh Harrier nest associated with nest DSR? To address these questions, we 
assessed the relevance of nest age, the fate of neighbouring nests and habitat variables at nest sites as possible predictors of the daily nest survival rate. Thus, we anticipated a higher DSR for better concealed nests over deeper water and situated in dense vegetation. We also hypothesized that Marsh Harrier DSR would decrease with increasing nest age and depend on neighbouring nest success. Determining these patterns of nest survival may improve our understanding of predator-prey interactions. It is also important for understanding raptor population dynamics, as reliable estimates of nest survival are essential for assessing relevant conservation strategies

\section{MATERIAL \& METHODS}

Study area

The study was conducted over five breeding seasons (2008, 2009, 2011, 2018 and 2019) in eastern Poland on four fishpond complexes: Siedlce, Rudka, Szostek, Mościbrody $\left(52^{\circ} 05-52^{\circ} 11\right.$

'N, $21^{\circ} 58-22^{\circ} 18^{\prime} \mathrm{E}$ ); all are mainly used for the commercial breeding of Common Carp Cyprinus carpio. Pond areas varied from 47 to 83 ha and were surrounded by a mixture of arable fields (50-60\%) where mostly cereals were cultivated, meadows (25-30\%) and forested areas (5-25\%). All four fishpond complexes were located within $20 \mathrm{~km}$ of each other. Most of the ponds were partially covered by tall marsh vegetation consisting of Bulrush (Common Reedmace) Typha latifolia, Common Reed Phragmites australis and Sedges Carex spp. These plants tend to proliferate rapidly, quickly covering the surface of a pond or wetland, thus creating a suitable breeding habitat for Marsh Harrier. The ponds were similar in water depth but water levels in the emergent vegetation varied from 7 to $92 \mathrm{~cm}$ in spring, falling as the breeding season progressed.

During the fieldwork, the presence of several possible opportunistic predators of aquatic birds' nests were recorded: the invasive American Mink Neovison vison and Raccoon dog Nyctereutes procyonoides, and the native Wild Boar Sus scrofa, Red Fox Vulpes vulpes, European Otter Lutra lutra, European Badger Meles meles, Magpie Pica pica, Raven Corvus corax and White-tailed Eagle Haliaeetus albicilla. With its rapid colonization of Poland in recent years, American mink is currently considered the biggest threat to the native waterbird fauna (Brzeziński et al., 2019a; Brzeziński et al., 2019b).

Field procedures 
124 At the beginning of each breeding season, each study pond was visited at 1-3-day intervals

125 between mid-April and mid-May to locate breeding pairs and nests. The observations were made with $8 \times 42$ binoculars from the fishpond dyke. The birds were observed carrying nest material to the emergent vegetation belt and during aerial food-passes near their potential nest site. After selecting a potentially favourable site, the observers inspected the vegetation belt on foot along fixed line transects. When located, the nests were numbered and their positions recorded with a hand-held GPS unit. A total of 82 nests were discovered in the study areas -27 during the egglaying phase, 53 during egg incubation and 2 during the early nestling period. To minimize disturbance, each nest was visited at 5-7 day intervals to determine clutch size, hatching date, nest fate and the number of live chicks. The first-egg laying date was calculated on the assumption that eggs are laid at 2-day intervals, and that incubation starts after the laying of the first egg and lasts for an average of 33 days (Witkowski, 1989). A nest was considered to have been depredated when clear signs (egg shells or nestling feathers) were found or the nest was found empty before the predicted date of fledging. A successful nest was defined as one where at least one young bird survived up to 35 days old (Witkowski, 1989). To be sure of this success, additional inspections of such a nest were made five days before and three days after this period. Six habitat variables were obtained for each active nest along with the fate of the nearest neighbour nest (Table 1). All the vegetation measurements (height, diameter and density) were made in $100 \times 100 \mathrm{~cm}$ quadrats placed around the nest during the first visit. The distances of a nest to the fishpond dyke and to open water was measured using GPS equipment. All operations were conducted as part of the "Research of birds in the disclimax ecosystems" programme, approved by the Institute of Biological Sciences, Siedlce University of Natural Sciences and Humanities (number of approval: IB.5030.8.2018). The study took place in compliance with current Polish Law and was approved by Ministry of the Environment (permit number: 425/2019) and also by the Regional Directorate for Environmental Protection in Warsaw (permit number: WSTS.6401.34.2018.MO).

\section{Statistical analyses}

Daily survival rate (DSR), the probability that a nest will survive a single day, was calculated using known-fate models with the RMark package (Laake, 2019). RMark is an R package (R Core Team, 2019) that provides a formula-based interface for the MARK program (White \& 
155 Burnham, 1999). The analysis covered only nests which succeeded or were depredated $(N=82)$.

156 The dates were scaled such that day 1 was the day when the first nest was found and day 84 was the day the last nest was checked. Hence, the 84-day nesting season was defined as beginning on $30^{\text {th }}$ April and ending on $22^{\text {nd }}$ July. The season thus consisted of 83 intervals, which represent an 83-day nesting cycle with each interval equivalent to one day. We therefore modelled DSR as a function of temporal (nest age), the fate of the nearest neighbour nest and habitat variables (water depth under the nest, density of reed stems, height and diameter of vegetation, distance to open water and distance to the dyke). The multi-co-linearity of habitat variables was checked - the correlations between them were $<0.4$. We constructed models of nest survival that incorporated combinations of individual covariates, and compared them to the null model of constant survival rate $\mathrm{S}($.$) . The set of competing models was based on a combination of factors assumed a priori to$ affect DSR.

The better concealed nests were expected to have a greater chance of survival. We used an information-theoretic approach (AIC) to compare the competing models (Burnham \& Anderson, 2002) and analysed model support using the AICc value, which corrects for small sample sizes and evaluates the strength of evidence for each model using normalized weights $\left(w_{i}\right)$. We applied selection approach suggested by Richards (2008), in which more complex variants of any model with a lower AICc value are excluded from the candidate set. The models selected with the smallest AICc as being the best of all the models compared, where the models were within a $\triangle \mathrm{i}$ AIC of 2.00 , were considered to be equally supported (Burnham \& Anderson, 2002).

\section{RESULTS}

We monitored a total of 82 Marsh Harrier nests: 52 were successful and 30 were depredated. The breeding success (at least one fledgling produced) over all the study years was 64\%; success was the highest (84\%) in 2011 and the lowest (9\%) in 2018, when only one pair successfully raised young (Table 2). Eight (27\%) of the nests were predated during the egg-laying stage, $16(53 \%)$ during incubation and $6(20 \%)$ during the nestling period. The average height of the reed stems in the nesting squares was $1.9 \mathrm{~m}(\mathrm{SD}=39.2 ; N=82$; range 106-300) and the average diameter of the shoots was $7.3 \mathrm{~mm}(\mathrm{SD}=1.8 ; N=82$; range $3.3-12.1)$. The density of stems varied between 31 and $191($ mean $=86.9 ; \mathrm{SD}=31.1 ; N=82)$. The level of water at the nest at the beginning of 
186

187

188

189

190

191

192

193

194

195

196

197

198

the nesting season varied between 21 and $92 \mathrm{~cm}($ mean $=50.4 ; \mathrm{SD}=15.6 \mathrm{~cm} ; N=82)$. The average distance of a nest to the fishpond dyke was $69.8 \mathrm{~m}(\mathrm{SD}=49.1 ; N=82$; range $15-233)$ and the average distance of a nest to open water was $51.0 \mathrm{~m}(\mathrm{SD}=50.2 ; N=82$; range 1-278).

In the null model, DSR calculated for all nests was 0.992 $\pm 0.001 \mathrm{SE}(95 \%$ CI [0.9890.994]). The analysis revealed that both temporal and habitat variables as well as fate of neighbouring nest affected Marsh Harrier DSR (Table 3). The top model of the 14 a priori models with the highest ranking ( $\mathrm{AICc}=194.1$ ) received $80 \%$ support (sum of $w_{i}$, Table 3 ) and included combinations of nest age, fate of neighbouring nest and two habitat variables (diameter of reed stems and water depth). The best-fitted model with the lowest AICc predicted that Marsh Harrier DSR gradually decreased with nest age (Fig. 1). The habitat factors with the greatest influence on the likelihood of nest depredation were the diameter of reed stems around the nest and water depth: in both cases, DSR gradually increased with these parameters (Fig 1). In addition, the chance of nest survival was smaller if a neighbouring nest was depredated (Fig 2). The analysis also showed that factors such as density of vegetation, distance to open water and distance to the fishpond dyke had no effect on the survival of Marsh Harrier broods. There was greater support for the null model of constant survival rate $\mathrm{S}($.$) .$

\section{DISCUSSION}

\section{Nest Age}

Our results showed that Marsh Harrier DSR was not constant from the egg phase to fledging, decreasing gradually with nest advancement. It is likely that multiple factors influence agespecific patterns of nest survival. One potential explanation of this pattern is that after hatching, parents and young provide more behavioural cues at the nest, which increase the possibility of its being detected by predators. Increased parental visits to the nest may raise the risk of nest predation (Martin, Scott \& Menge, 2000). Indeed, in the late nesting period, Marsh Harrier parents make more food deliveries daily (Kitowski, 2006). However, as nest age increases, adults invest more in the nest and typically intensify defensive behaviour (Caro, 2005); this pattern has also been confirmed in other birds of prey (Carrillo \& Aparicio, 2001; Sergio \& Bogliani, 2001). Despite the fact that Marsh Harrier actively defend its nests (Kitowski, 2006), this does not compensate for increased predation. One possible explanation is that with nest advancement, parents need to make more frequent foraging flights to provide for their offspring and spend less 
217 their time defending the nest. The times when the parents are absent are when the nest is more

218 vulnerable to predation. Decreasing DSR may also reflect a cumulative risk: the longer a nest is active, the more likely it will lose eggs to predation. In Marsh Harrier, the period from the start of incubation to the fledging of the young birds is relatively long in comparison with other species nesting in the same fishpond habitat. For example, chicks of Eurasian Bittern (Botaurus stellaris) leave the nest at the age of just two weeks post hatching, i.e. before reaching full independence (Kasprzykowski \& Polak, 2012). The female continues to care for the young, which hide in vegetation near the nest until fully fledged. This could be an adaptive strategy diluting the risk of detection by predators and preventing DSR from decreasing with nest age in this species. In contrast, Marsh Harrier chicks cannot leave the nest until they are capable of flight: this species is therefore especially vulnerable to detection by predators with increasing nest advancement.

\section{Nest concealment}

In our study, the diameter of reed stems but not the density or height of vegetation influenced Marsh Harrier nest DSR. Nests built over deeper water, where reed stems were thicker, were less vulnerable to predation. Nests located in sites with thicker vegetation may be better protected from predators because the habitat structure at these sites may improve visual concealment of nest thus reducing probability of nest detection. Vegetation thickness can also improve protection from wind thus reducing olfactory cues to potential mammal predators (see Guyn \& Clark, 1997). The height of the vegetation was not a variable significantly improving the chances of brood success in Marsh Harrier; this factor has been proven significant, though mostly for populations of birds depredated by avian predators (Jedlikowski, Brzeziński \& Chibowski, 2015). The distances from nests to open water or the fishpond dyke were not significant. This finding is consistent with previous studies on this species (Stanevičius, 2004). It is well-known that ground-nesting birds, including Marsh Harrier, are particularly vulnerable to predation. Thus, obligate ground-nesters have evolved a method of placing their nests in well-concealed, evenly-spaced sites to reduce the likelihood of detection (Redmond, Keppie \& Herzog, 1985). We expected the density of vegetation to have an impact on nest DSR of Marsh Harrier, as was found to be the case in other marsh nesting birds (Kristiansen, 1998; Polak, 2016). The reason for the lack of such a relationship is that parental behaviour (nest defence) may compensate for 
248

249

any effects of insufficient nest cover (Lima \& Dill, 1990). Marsh Harrier is considered a top avian predator of wetland habitats and actively defends its own nests with alarm calls and physical attacks (Witkowski, 1989).

\section{Water depth}

A strong positive relationship between water depth and nest survival has been observed in marsh-nesting birds, e.g. in Eurasian Bittern (Polak, 2016) and Common Pochard Aythya ferina (Albrecht et al., 2006). In the present study, Marsh Harrier nests located at sites with deeper water exhibited the same trait. Such nests were particularly successful, because water presents a barrier to many mammalian predators (Koons \& Rotella, 2003). It is worth noting that the water level is not constant throughout the breeding season. Previous studies have shown that predation rates for wetland nesters decreased with increasing water depth (Purger \& Mészáros, 2006). On the other hand, water depth was not important for the DSR of either Little Crake Porzana parva or Water Rail Rallus aquaticus, as their main predators are mostly avian (Jedlikowski, Brzeziński \& Chibowski, 2015). This pattern suggests that Marsh Harrier builds its nests over deeper water because they are more susceptible to predation by mammals than by birds. The relationship between a low water level and mammalian predation was demonstrated in the Netherlands, where Red Fox was a frequent predator of Marsh Harrier nests in dry reedbeds (Dijkstra \& Zijlstra, 1997). In his study of a breeding population of Marsh Harrier in the Barycz Valley, Witkowski (1989) also noted that dried out ponds were avoided, although the same ponds containing water could have one of the highest densities of nesting pairs. This may suggest that locating nests at deep water sites is an important antipredator strategy in this species. During studies in eastern Poland thirty years ago, Buczek \& Keller (1994) highlighted corvids and mustelids as being the main predators of Marsh Harrier nests on retention reservoirs (mostly resembling neglected fishponds) and bogs, respectively. This was further explained by the low water level in bogs, decreasing during the course of the season, which enabled mammalian predators to penetrate reedbeds. Since that study, predator and prey interactions could well have changed significantly, following the spread of non-native invasive predators such as American Mink. This has been confirmed by recent research, which links the declines of several waterbirds and semi-aquatic mammals with the colonization of Poland by American Mink (Brzeziński et al., 2019b). Even though water is not a barrier for American Mink, the occurrence of this invasive 
279 species may also be having an impact on Marsh Harrier, making it even more vulnerable to mammalian predation. But to explain this possible shift, further studies will be needed to evaluate the causes of nest loss in Marsh Harrier in greater detail.

\section{Neighbour fate}

The influence of nearest neighbour fate on nest success has been addressed in observational and experimental studies, but their results are inconsistent (Ackerman, Blackmer \& Eadie, 2004; Ringelman, Eadie \& Ackerman, 2012). In our study, the chances of nest survival were lower if a neighbouring nest was depredated. A similar pattern is observed in other marsh nesting birds like Common Pochard Aythia ferina (Folliot et al., 2017). In other wetland bird species, nearestneighbour nests tend to share the same fate but only when they form clusters, which survive or are depredated as a group (Ringelman, Eadie \& Ackerman, 2012; Kasprzykowski \& Polak 2014). The reason why neighbours' fates influence a nest's fate is that predators use arearestricted searching and employ search images to find similar nests nearby. However, other studies on waterfowl have not detected any influence of nearest neighbour fate on the success of artificial or natural nests (Ackerman, Blackmer \& Eadie, 2004). The reason for this difference could be the predator community and the spatial scale at which potential predator species operate i.e. large vs. small home ranges (Schmidt \& Whelan, 1999).

\section{CONCLUSIONS}

Our study has shown that the daily survival rate of Marsh Harrier is influenced by both temporal and certain habitat variables. DSR is the highest at the beginning of the nesting season and decreases gradually with nest advancement. Water depth and the mean diameter of vegetation at the nest site were the habitat variables influencing Marsh Harrier DSR. This result suggests that Marsh Harriers are more susceptible to mammalian than avian predation. The relationship between nest survival and nearest neighbour nest fate seems to confirm the high level of predator pressure in fishpond habitats. Further studies are needed in order to gain a better understanding of the accessibility of wetland birds' nests to terrestrial predators in the context of biological invasions.

\section{ACKNOWLEDGEMENTS}


310 We are grateful to Karol Bosek, Rafał Kuropieska, Daniel Paczóski, Marta Szaniawska, Kamil

311 Kryński, Tomasz Pietrzak, Paweł Radzikowski, Monika Budzyńska and Cezary Sadowy for their

312 help in carrying out the fieldwork. We would like to also thank Jay Rotella for helping with the 313 statistical analyses.

\section{REFERENCES}

Ackerman JT, Blackmer AL, Eadie JM. 2004. Is predation on waterfowl nests density dependent? - Tests at three spatial scales. Oikos 107: 128-140. DOI 10.1111/j.00301299.2004.13226.x.

Albrecht T, Horak D, Kreisinger J, Weidinger K, Klvana P, Michot TC. 2006. Factors Determining Pochard Nest Predation Along a Wetland Gradient. Journal of Wildlife Management 70:784-791 DOI 10.2193/0022-541X(2006)70[784:FDPNPA]2.0.CO;2.

Alves M, Ferreira J, Torres I, Fonseca C, Matos M. 2014. Habitat Use and Selection of the Marsh Harrier Circus aeruginosus in an Agricultural-Wetland Mosaic. Ardeola 61:351-366 DOI 10.13157/arla.61.2.2014.351.

Austin JE, Buhl DA. 2011. Nest survival of American Coots relative to grazing, burning, and water depths. Avian Conservation and Ecology 6:1 DOI 10.5751/ACE-00472-060201.

Batáry P, Báldi A. 2005. Factors affecting the survival of real and artificial Great Reed Warbler's nest Biologia, Bratislava 60: 215-219.

Brown JL. Steenhof K, Kochert MN, Bon L. 2013. Estimating Raptor Nesting Success: Old and New Approaches. Journal of Wildlife Management 77:1067-1074 DOI 10.1002/jwmg.566.

Brown JL, Collopy MW. 2008. Nest-Site Characteristics Affect Daily Nest-Survival Rates of Northern Aplomado Falcons (Falco Femoralis Septentrionalis) The Auk 125:105-112 DOI 10.1525/auk.2008.125.1.105.

Brzeziński M, Żmihorski M, Zarzycka A, Zalewski A. 2019a. Expansion and population dynamics of a non-native invasive species: the 40-year history of American mink colonisation of Poland. Biological Invasions 21:31-545 DOI 10.1007/s10530-018-1844-7.

Brzeziński M, Żmihorski M, Nieoczym M, Wilniewczyc P, Zalewski A. 2019b. The expansion wave of an invasive predator leaves declining waterbird populations behind. Diversity and Distributions 26: 138-150 DOI 10.1111/ddi.13003. 
Brzeziński M, Jedlikowski J, Żmihorski M. 2013. The effect of nest site on the nesting success of the Coot Fulica atra. Ornis Fennica 90:57-64.

Buczek T, Keller M. 1994. Breeding ecology of the Marsh Harrier Circus aeruginosus in eastern Poland. Part 2. Causes of brood losses. Acta Ornithologica 29:81-88.

Burnham KP, Anderson DR. 2002. Model Selection and Multimodel Inference. Heidelberg: Springer.

Cardador L, Carrete M, Manosa S. 2011. Can intensive agricultural landscapes favour some raptor species? The Marsh Harrier Circus aeruginosus in Northeaster Spain. Animal Conservation 14:382-390 DOI: 10.1111/j.1469-1795.2011.00449.x.

Carrillo J, Aparicio JM. 2001. Nest defence behaviour of the Eurasian kestrel (Falco tinnunculus) against human predators. Ethology 107:865-875.

Caro TM. 2005. Antipredator defenses in birds and mammals. Chicago University Press, Chicago.

Crandall RH, Bedrosian BE, Craighead D. 2015. Habitat Selection and Factors Influencing Nest Survival of Golden Eagles in South-Central Montana. Journal of Raptor Research 49:413428 DOI 10.3356/rapt-49-04-413-428.1.

Davison WB, Bollinger E. 2000. Predation Rates on Real and Artificial Nests of Grassland Birds. The Auk 117:147-153 DOI 10.1093/auk/117.1.147.

Dijkstra C, Zijlstra M. 1997. Reproduction of the Marsh Harrier Circus aeruginosus in recent land reclamations in the Netherland. Ardea 85:37-50.

Dinsmore SJ, White GC, and Knopf FL. 2002. Advanced techniques for modeling avian nest survival. Ecology 83:3476-3488.

Ellis DH, Craig T, Craig E, Postupalsky S, LaRue CT, Nelson RW, Anderson DW, Henny CJ, Watson J, Millsap BA, Dawson JW, Cole KL, Martin EM, Margalida A, Kung P. Unusual Raptor Nests Around The World. 2009. Journal of Raptor Research 43:175-198 DOI 10.3356/JRR-08-110.

Folliot B, Caizergues A, Barbotin A, Guillemain M. 2017. Environmental and individual correlates of common pochard (Aythya ferina) nesting success. European Journal of Wildlife Research 63.

Grant TA, Shaffer TL, Madden EM, Pietz PJ. 2005. Time specific variation in passerine nest survival: New insights into old questions. The Auk 122:661-672 
DOI 10.1093/auk/122.2.661.

Guyn KL, Clark RG. 1997. Cover Characteristics and Success of Natural and Artificial Duck Nests. Journal of Field Ornithology 68:33-41.

Hoover JP. 2006. Water depth influences nest predation for a wetland-dependent bird in fragmented bottomland forests. Biological Conservation 127:37-45 DOI 10.1016/j.biocon.2005.07.017.

Ibáñez-Álamo JD, Magrath RD, Oteyza JC, Chalfoun AD, Haff TM, Schmidt KA, Thomson RI, Martin TE. 2015. Nest predation research: recent findings and future perspectives. Journal of Ornithology 156:247-262 DOI 10.1007/210336-015-1207-4.

Jedlikowski J, Brzeziński M, Chibowski P. 2015. Habitat variables affecting nest predation rates at small ponds: a case study of the Little Crake Porzana parva and Water Rail Rallus aquaticus. Bird Study 62:190-210 DOI 10.1080/00063657.2015.1031080.

Jobin B, Picman J. 1997. Factors Affecting Predation on Artificial Nests in Marshes. The Journal of Wildlife Management 61:792-800 DOI 10.2307/3802186.

Kasprzykowski Z, Polak M. 2012. Habitat quality and breeding parameters in relation to female mating status in the polygynous Eurasian Bittern Botaurus stellaris. Journal of Ornithology 154:403-409 DOI 10.1007/s10336-012-0904-5.

Kasprzykowski Z, Polak M. 2014. Environmental variables predict timing of breeding in the polygynous Eurasian bittern Botaurus stellaris. Folia Zoologica 63:188-193.

Kitowski I. 2006. Breeding Behaviour of Eurasian Marsh Harriers (Circus aeruginosus L., 1758; Aves, Accipitridae) Nesting on Three Habitats in Eastern Poland. International Journal of Zoological Research 2: 169-177 DOI: 10.3923/ijzr.2006.169.177.

Koons DN, Rotella JJ. 2003. Comparative nesting success of sympatric Lesser Scaup and Ringnecked Ducks. Journal of Field Ornithology 74:222-229 DOI 10.1648/0273-857074.3.222.

Kristiansen JN. 1998. Egg predation in reedbed nesting graylag geese Anser anser in Vejlerne, Denmark. Ardea 86:137-145.

Laake JL. 2019. RMark: An R interface for analysis of capture-recapture data with MARK. Seattle, WA. Retrieved from https://cran.r-project.org/web/packages/RMark/RMark.pdf Lima SL, Dill ML. 1990. Behavioral decisions made under the risk of predation: a review and prospectus. Canadian Journal of Zoology 68:619-640 DOI 10.1139/z90-092. 
Lima SL. 2009. Predators and the breeding bird: behavioral and reproductive flexibility under the risk of predation. Biological Reviews 84:485-513 DOI 10.1111/j.1469-185X.2009.00085.x.

Martin TE, Scott J, Menge C. 2000. Nest predation increase with parental activity: separating nest site and parental activity effects. Proceedings of the Royal Society B: Biological Sciences 267:2287-2293 DOI 10.2307/1311947.

Němečková I, Mrlík V, Drozd, P. 2008. Timing of breeding, habitat preference and reproductive success of Marsh Harriers (Circus aeruginosus). Biologia 63:261-265 DOI 10.2478/s11756-008-0030-2.

Pestana GC, Mateus-Barros E, Guillermo-Ferreira R. 2020. The influence of parent body colouration and nesting habitat on bird nest predation. Bird Study 67:29-34 DOI: $10.1080 / 00063657.2020 .1733486$.

Polak M. 2007. Nest-Site Selection and Nest Predation in the Great Bittern Botaurus stellaris Population in Eastern Poland. Ardea 95:31-38 DOI: 10.5253/078.095.0104.

Polak M. 2016. Nest survival patterns in Eurasian Bittern: effect of nest age, time and habitat variables. PeerJ. 4:e2047 DOI 10.7717/peerj.2047.

Purger JJ, Mészáros LA. 2006. Possible effects of nest predation on the breeding success of Ferruginous Ducks Aythya nyroca. Bird Conservation International 16:309-316 DOI $10.1017 /$ S0959270906000451.

R Core Team. 2019. R: A language and environment for statistical computing. R Foundation for Statistical Computing, Vienna, Austria. URL https:/www.R-project.org/.

Redmond GWD, Keppie DM, Herzog PW. 1982. Vegetative structure, concealment, and success at nests of two races of spruce grouse. Canadian Journal of Zoology 60:670-675 DOI 10.1139/z82-096.

Richards SA. 2008. Dealing with overdispersed count data in applied ecology. Journal of Applied Ecology 45:218-227 DOI 10.1111/j.1365-2664.2007.01377.x.

Ringelman KM, Eadie JM, Ackerman JT. 2012. Density-dependent nest predation in waterfowl: the relative importance of nest density versus nest dispersion. Oecologia 169:695-702 DOI 10.1007/s00442-011-2228-1.

Schmidt KA, Whelan CJ. 1999. Nest Placement and Mortality: Is Nest Predation a Random Event in Space and Time? The Condor 101:916-920 DOI: 10.2307/1370089. 
434 Segura LN, Bó MS. 2017. Breeding phenology and nest survival of Cinereous (Circus cinereus)

435 and Long-winged (C. buffoni) Harriers in the agricultural landscapes of north-east

436 Patagonia, Argentina. Emu - Austral Ornithology: 118:218-223

437 DOI 10.1080/01584197.2017.1404431.

438 Sergio F, Bogliani G. 2001. Nest defense as parental care in the northern hobby (Falco subbuteo). Auk 118:1047-1052.

Simmons R, Simmons JR. 2000. Harriers of the World: Their Behaviour and Ecology. Oxford University Press.

Smith PA, Wilson S. 2010. Intraseasonal patterns in shorebird nest survival are related to nest age and defence behaviour. Oecologia 163:613-624 DOI 10.1007/s00442-010-1644-y.

Stanevičius V. 2004. Nest-Site Selection by Marsh Harrier (Circus aeruginosus) in the Shore Belt of Helophytes on Large Lakes. Acta Zoologica Lituanica 14:47-53 DOI 10.1080/13921657.2004.10512591.

Sutherland JM, Maher WJ. 1987. Nest-site selection of the American Coot in the aspen parklands of Saskatchewan. The Condor 89:804-810 DOI 10.2307/1368528.

White GC, Burnham KP. 1999. Program MARK: survival estimation from populations of marked animals. Bird Study 46:120-139 DOI 10.1080/00063659909477239.

Witkowski J. 1989. Breeding biology and ecology of the Marsh Harrier (Circus aeruginosus) in the Barycz Valley, Poland. Acta Ornithologica 25:223-320. 


\section{Table 1 (on next page)}

Variables obtained at ponds with active Marsh Harrier nests. 
1 Code Meaning

Water Estimated water depth $(\mathrm{cm})$ at the centre of the plot with 1-cm precision

Height Mean height of 5 flowered dry reed stems chosen randomly with 10-cm precision

Diameter Mean diameter of 10 reed stems chosen randomly with a calliper precision of $0.1 \mathrm{~mm}$

Density Number of stems within a $1 \times 1 \mathrm{~m}$ square

Distdyke Distance (m) to the fishpond dyke

Distow Distance (m) to open water pool

NNFate $\quad$ Fate of the nearest neighbour nest: success (1) and loss (0) 
Table 2 (on next page)

Sample size of Marsh Harrier nesting attempts by year. 
1

\begin{tabular}{lccccc}
\hline Year & 2008 & 2009 & 2011 & 2018 & 2019 \\
\hline Depredated nests & 6 & 5 & 3 & 11 & 5 \\
Successful nests & 12 & 16 & 15 & 1 & 8 \\
\hline Total & 18 & 21 & 18 & 12 & 13 \\
\hline
\end{tabular}

2 


\section{Table 3(on next page)}

Summary of candidate DSR models of Marsh Harrier in eastern Poland

The number of estimated parameters (npar), Akaike's information criterion with small-sample bias adjustment $(\mathrm{AICC})$, delta $(\Delta \mathrm{i})$ representing the difference in $\mathrm{AICC}$ between the current and the most appropriate model, and the model weight $w_{i}$ are shown. 


\begin{tabular}{lccccc}
\hline Candidate model & npar & deviance & AICc & $\begin{array}{c}(\Delta \mathbf{i}) \\
\text { AICc }\end{array}$ & $\boldsymbol{w}_{\boldsymbol{i}}$ \\
\hline S( NestAge+Diameter+Water+NNFate $)$ & 5 & 184.035 & 194.1 & 0.00 & 0.795 \\
S( NestAge+Diameter+Water) & 4 & 189.179 & 197.2 & 3.14 & 0.165 \\
S( NestAge+Water+Distow) & 4 & 193.011 & 201.0 & 6.97 & 0.024 \\
S( NestAge+Water) & 3 & 196.880 & 202.9 & 8.83 & 0.009 \\
S( NestAge) & 2 & 200.342 & 204.3 & 10.3 & 0.004 \\
S( Diameter+Water) & 3 & 202.913 & 208.9 & 14.9 & 0.000 \\
S( Diameter) & 2 & 205.989 & 209.9 & 15.9 & 0.000 \\
S( NNFate $)$ & 2 & 206.401 & 210.4 & 16.4 & 0.000 \\
S( Water $)$ & 2 & 206.622 & 210.6 & 16.6 & 0.000 \\
S( Height $)$ & 2 & 208.680 & 212.7 & 18.6 & 0.000 \\
S( .) & 1 & 212.351 & 214.4 & 20.3 & 0.000 \\
S( Distdyke & 2 & 211.448 & 215.5 & 21.4 & 0.000 \\
S( Distow) & 2 & 211.605 & 215.6 & 21.5 & 0.000 \\
S( Density) & 2 & 212.047 & 216.1 & 21.9 & 0.000 \\
\hline
\end{tabular}




\section{Figure 1}

Model-averaged estimates of daily nest survival for Marsh Harrier in eastern Poland showing the effect of nest age $(A)$, mean diameter of vegetation $(B)$ and water depth (C).

The solid line represents the daily survival rate estimated using beta parameters from the bestfit model. The grey areas around the line represent the $95 \%$ confidence intervals for the estimated daily survival rate. 

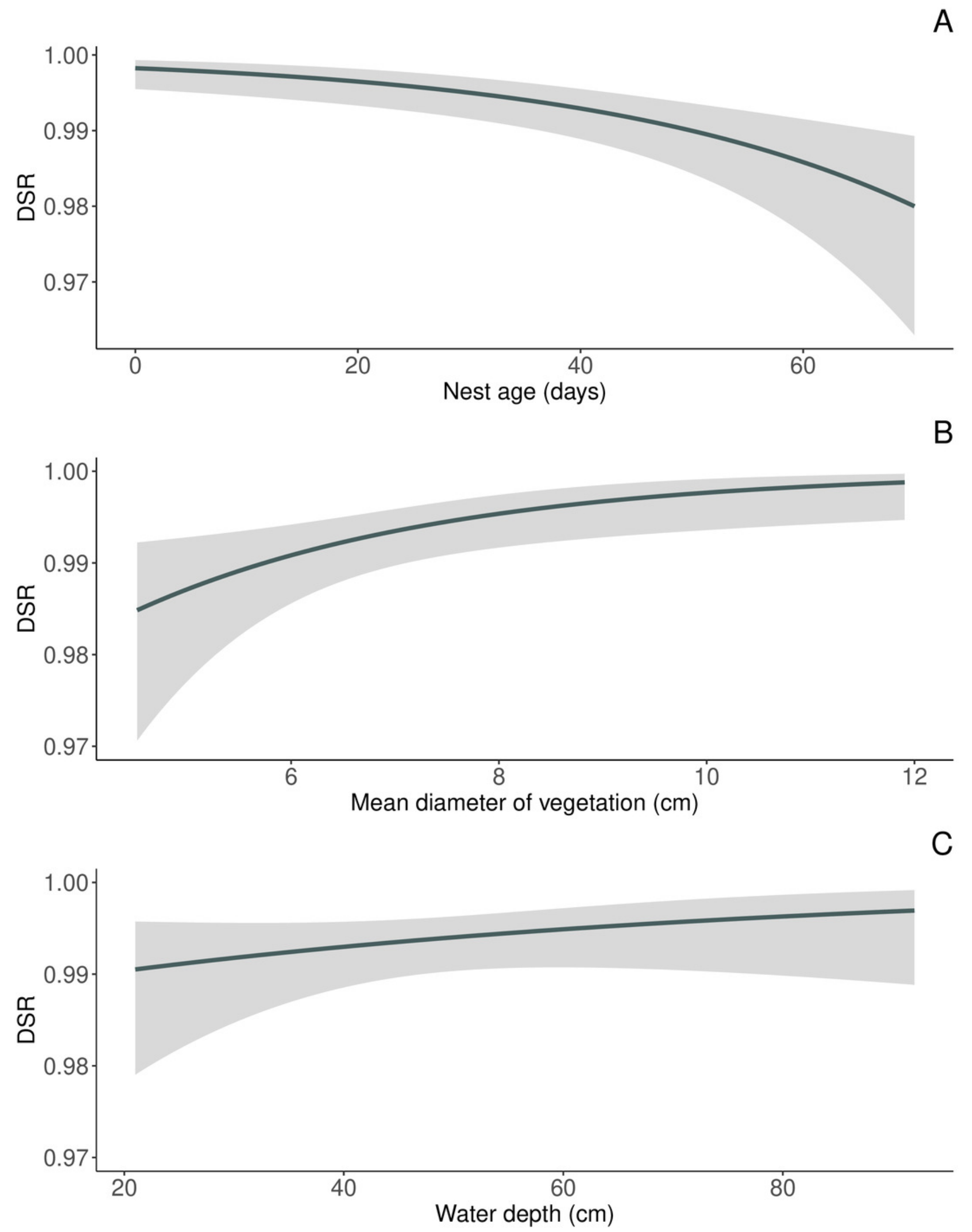
Figure 2

Median probability of nest survival (points) with $95 \% \mathrm{Cl}$ (whiskers) for nests for which the nearest neighboring nest was successful (success) or depredated (loss). 


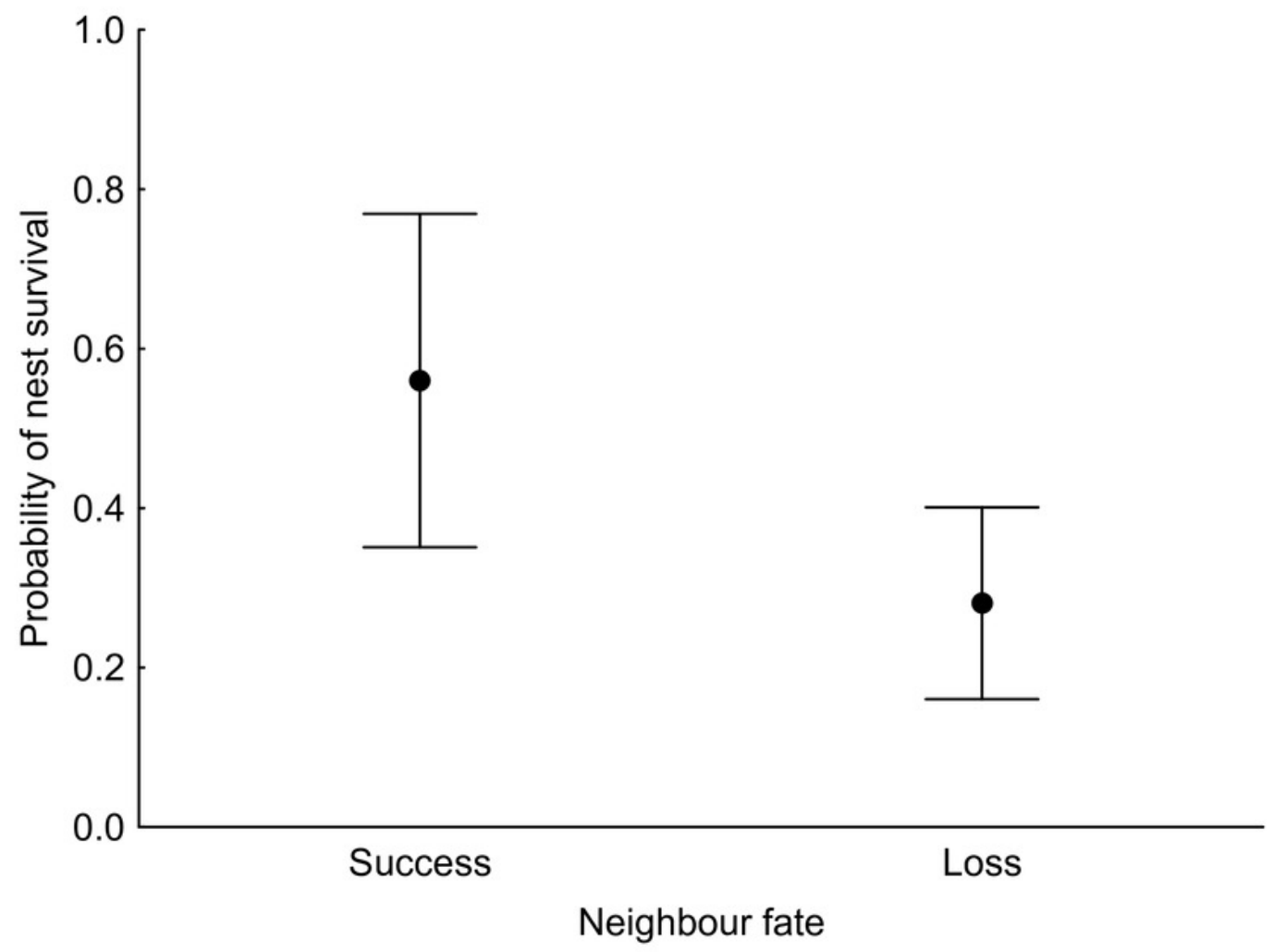

